\title{
Context Matters: The Effect of Racial Composition of State Electorates on White Racial Attitudes
}

\author{
James M. Avery and Jeffrey A. Fine
}

We examine the relationship between the racial composition of state electorates and white racial attitudes, arguing that the racial threat hypothesis should characterize this relationship. Specifically, we make the case for why greater black electoral strength should lead to more racially conservative policy preferences and more negative racial stereotypes among whites. Our findings are consistent with this expectation. However, this relationship is dependent on two contexts. We find that black electoral strength mattered in the context of the racially-salient 2008 national elections, but not during the 2000 or 2004 elections. Also, consistent with the racial threat hypothesis, we find that black electoral strength influences racial attitudes only among whites who have greater reason to fear economic competition from African Americans. Overall, our findings are consistent with recent studies demonstrating that the influence of racial composition on white racial attitudes is dependent on context.

The influence of racial composition (i.e., the percent of a region or constituency that is African American) on whites' racial attitudes has been studied extensively over the past six decades (e.g., Black 1978; Blalock 1967; Glaser 1994; Huckfeldt and Kohfeld 1989; Key 1949). One expectation is that greater racial diversity will lead to more tolerant racial attitudes among whites (e.g., Bledsoe et al. 1995). The "racial threat hypothesis" (RTH), however, argues that racial diversity will result in more negative racial attitudes and support for more racially conservative policies among whites (e.g., Blalock 1967; Huckfeldt and Kohfeld 1989; Key 1949). ${ }^{1}$ The $\mathrm{RTH}$ is less a hypothesis and more of a general theory, which is based on the expectation that whites are threatened by competition from large, empowered black populations. Recent research provides mixed support for these competing theories and highlights the need to consider characteristics of the geographic context, as well as other contexts (e.g., economic context) when considering the influence of racial composition on white racial attitudes (Baybeck 2006; Branton and Jones 2005; Oliver and Wong 2003).

The current study focuses on racial context in the American states, a geographic unit that has been neglected in the existing literature. Adding to recent research highlighting the need to consider geographic context, we first offer our theory for why we expect the RTH to characterize the relationship

James M. Avery is Associate Professor of Political Science at Richard Stockton College of New Jersey, Galloway, NJ. Jefrerey A. Fine is Associate Professor of Political Science at Clemson University, Clemson, South Carolina.

The American Review of Politics, Vol. 33, Fall, 2012: 211-231

(c)2012 The American Review of Politics 
between racial diversity in the states and white racial attitudes. Rather that examining racial diversity in the state population as most studies do, we focus on racial diversity in the electorate, what we term "black electoral strength." Our focus on black electoral strength is justified given the RTH's focus on whites' fear of competition from politically empowered African Americans. We also propose three potential contextual factors that may moderate the relationship between black electoral strength and white racial attitudes, including region, racial salience of the times (the 2008 presidential election, specifically), and economic threat. We then present our data and test several hypotheses that follow from the theory. The current study makes two general contributions. First, we demonstrate that the RTH characterizes the relationship between black electoral strength and white racial attitudes at the state level. Second, we identify two contexts that moderate the relationship between black electoral strength and white racial attitudes. Beyond these general contributions, our findings also add to scholarly discussion about the role of race during the 2008 presidential election.

\section{Racial Context and White Racial Attitudes}

There are two competing theories on how racial context influences white racial attitudes. One theory predicts that racial diversity will cause whites to be more racially tolerant. This expectation is derived primarily from "contact theory," which argues that greater interracial contact will lead to greater understanding across racial groups, and thus less prejudice and greater tolerance of out-groups (e.g., Allport 1954). Some recent research finds support for this expectation (Bledsoe et al. 1995; Oliver and Wong 2003; Sigelman and Welch 1993; Welch et al. 2001). For example, Oliver and Wong (2003) find that interethnic diversity in neighborhoods - where interethnic contact is likely-is associated with lower levels of out-group prejudice and competition.

In contrast to contact theory, the RTH predicts that racial diversity will lead to interracial competition for scarce resources (i.e., realistic group conflict; e.g., Campbell 1965) and political power (Blalock 1967), causing whites to feel threatened by large black populations. Motivated by this threat, whites will then hold more racially conservative policy preferences and more negative attitudes toward African Americans (Black and Black 1987; Glaser 1994; 2001; Huckfeldt and Kohfeld 1989; Key 1949; Taylor 1998). Other work finds a link between racial diversity and whites' support for racially conservative candidates (Giles and Buckner 1993; Wright 1977).

Beyond the debate regarding the direction of the effect of racial context, there also is a debate about the appropriate geographic unit (e.g., state, county, city, neighborhood) for examining the influence of context on 
whites' attitudes and behavior. We contend that one geographic unit is not more appropriate than others, but rather that racial context at different levels of aggregation may influence white racial attitudes in distinct ways. Recent research finds support for contact theory in smaller geographic contexts, but there is reason to question its applicability when examining racial context in the states. Early proponents of contact theory identified a number of conditions that are necessary for racial diversity to reduce prejudice (Allport 1954; Pettigrew 1971; Amir 1976). Perhaps the most important and obvious condition is the need for interracial contact. Indeed, studies that find a positive relationship between racial diversity and white racial attitudes and behavior examine geographic units that are much smaller than the state (e.g., municipalities or neighborhoods; Bledsoe et al. 1995; Carsey 1995; Oliver and Wong 2003; Welch et al. 2001). Using municipalities or neighborhoods as the geographic unit of study makes it more likely that racial diversity will be accompanied by the sort of interracial contact that fosters interracial understanding and cooperation. However, while geographic racial segregation is not institutional, it continues to be the norm rather than the exception (Oliver and Mendelberg 2000; Massey 2000). As such, states with large black populations are not necessarily going to have equally large amounts of the neighborhood-level interracial contact found to promote interracial cooperation. Indeed, recent research finds that whites' policy attitudes are conditioned by the extent of segregation. Specifically, Rocha and Espino (2009) find that whites in areas with large, but segregated Latino populations provide greater support for making English an official language and are more likely to believe that there are too many immigrants coming to this country than whites living in areas with large, but less segregated Latino populations. In sum, while some racial contexts may produce greater inter-racial cooperation, the extent of racial segregation in states suggests that greater racial diversity should lead to greater inter-racial animosity at the state level.

Not only is it unlikely that racial diversity will be accompanied by substantial interracial contact, but there also is significant competition for resources at the state level. Competition over economic and political resources is central to early theories of racial threat (Blalock 1967; Key 1949). Recent research also focuses on competition over resources as the source of whites' feelings of racial threat (Baybeck 2006; Glaser 2001; Liu 2001; Oliver and Mendelberg 2000). For example, Baybeck (2006) finds that whites living in racially homogeneous neighborhoods, but neighborhoods in cities where racial competition for power still exists, are less satisfied with local government than whites living in homogeneous neighborhoods with less racial competition. That is, when there is little interracial contact, white racial attitudes and policy preferences are dependent on the degree of interracial competition for resources, which increases with greater racial 
diversity. Similarly, Oliver and Mendelberg (2000), studying metropolitan areas, find that racial diversity is associated with greater racial antagonism and conclude that ". . . interracial material competition shapes white racial attitudes primarily on specific policies, when there is a direct connection between the resources being contested and the geographic area in which it is contested or distributed" (587). Finally, Liu (2001) distinguishes between racial context in election (i.e., political) units and neighborhood (i.e., social) units and finds that the racial context of the electoral unit-where interracial competition for political power takes place-is a stronger predictor of the white vote than the racial context of the social unit. All these recent studies suggest that racial diversity may lead to more negative racial attitudes among whites when there is congruence between the level at which racial diversity exists and the level at which competition for resources takes place, as is the case at the state level. Indeed, research examining racial composition of states has found that greater racial diversity is associated with more conservative social welfare policies (Radcliff and Saiz 1995; Soss et al. 2001) and that greater racial tension in the states led to less support for Senator Obama during the 2008 presidential election (Liu 2010), both findings consistent with the RTH. ${ }^{2}$

On the whole, the literature suggests that if racial composition within states does influence whites' attitudes, we should expect greater racial diversity to lead to more negative racial attitudes. Given this, we propose two initial hypotheses. First, we expect that whites living in states with greater black electoral strength (our measure of racial context) will prefer less government intervention to aid African Americans than will whites living in states with less black electoral strength. Second, we expect that whites living in states with greater black electoral strength will be more likely to hold negative racial stereotypes than whites living in states with less black electoral strength. The effect of black electoral strength on white racial attitudes, however, may be moderated by various contextual factors. Below we discuss three potential moderating contextual factors.

\section{Contextual Factors}

\section{Region}

The first context we consider is region. Given the history of slavery and interracial animosity in the South, we may expect the RTH to find greater support among whites living in southern states (but see Taylor 1998). Indeed, the RTH was initially proposed as an explanation for whites' attitudes and voting behavior in the American South (e.g., Key 1949). Moreover, racial intolerance among whites continues to be greater in the South than the 
rest of the country (Kuklinski et al. 1997). Consequently, we propose two additional hypotheses to be tested: that the negative effect of black electoral strength on support for government aid to African Americans and the positive effect of black electoral strength on negative stereotypes of blacks will be stronger among whites living in the South than among whites living outside the South.

\section{Racial Salience of the Times}

The second context we consider is the racial salience of the times. The salience of race and racial issues in public dialogue has varied a great deal over time, and is likely to moderate the effect of the black electoral strength on white racial attitudes. Most recently, we saw an increase in the salience of race during the 2008 presidential election as the result of two related but distinct characteristics of the campaign. First, the race of the presidential candidates was especially prominent during the election. This was the first election where an African-American candidate was competitive in the general election. Consequently, many whites feared that if Senator Obama won the election, that he would provide better representation of black interests at the expense of white interests. For example, a survey by the Cooperative Campaign Analysis Project found that 56 percent of whites believed that if Obama were elected he would favor blacks (cited in Lewis-Beck et al. 2010). Indeed, one study estimates that racial resentment among whites reduced the net vote for Obama by five percentage points (Lewis-Beck et al. 2010), while another study finds that negative stereotypes among whites significantly eroded support for Obama (Piston 2010; see also Ansolabehere et al. 2010 for evidence that race still plays a role in many whites' voting behavior). A third study concludes that higher levels of racial tension in a state during the 2008 election substantially decreased Obama's vote share (Liu 2010).

Having a viable African-American candidate also increased the salience of race because it led to a surge in African-American voter turnout. This surge in black voting became evident during the Democratic primary contests and received a great deal of attention from the news media. ${ }^{3}$ News coverage of high turnout rates among blacks began as early as January, 2008, as strong levels of black mobilization fueled Senator Obama's early primary victories over Senator Clinton (e.g., Balz et al. 2008). Moreover, the press gave considerable attention to prominent African-American leaders who sought to mobilize the black vote by suggesting that it could be pivotal (Leary 2008). Other news reports focused specifically on the expanded electoral strength of African Americans due to their spike in registration. For example, news reports gave a great deal of attention to how the increased 
number of registered African Americans in Georgia gave the group additional voting power (e.g., Hulse 2008). With widespread news coverage of the potential increase in electoral strength of African Americans, it is reasonable to assume that white voters were aware of the changing electoral landscape in 2008. As such, fear of interracial competition among whites was likely greater during the 2008 election than during recent previous elections.

In summary, given the extent of news coverage of the increased turnout among blacks and the otherwise high salience of race given the candidacy of Senator Obama, there is substantial reason to expect the RTH to be stronger during the 2008 campaign than other recent elections. Hence, we pose two more hypotheses: that the negative effect of black electoral strength on support for government aid to African Americans and the positive effect of black electoral strength on negative stereotypes of blacks will be stronger during the 2008 election than during the 2000 and 2004 elections. ${ }^{4}$

\section{Economic Threat}

Finally, we also consider how individuals' economic context may moderate the effect of black electoral strength on racial attitudes. According to the RTH, fear of economic competition drives whites' fear of large black populations. For example, Key (1949) argued that fear of competition over economic power was at the root of race relations in the southern "black belt" and was the driving force behind whites' opposition to equal rights for African Americans (see also Blalock 1967). Recent research also emphasizes the importance of economic context when considering the influence of racial context on whites' attitudes. For example, Quillian (1995) concludes that prejudice among members of dominant groups is primarily a function of group threat based on the relative size of the subordinate group and the degree of economic threat faced by the dominant group. Likewise, Branton and Jones (2005) find that greater racial diversity is associated with greater support for conservative racial policies among whites living in poorer socioeconomic areas. The opposite effect is found for whites living in areas that are more affluent and thus characterized by less interracial economic competition.

By considering the moderating effect of whites' economic evaluations we will more directly test the influence of threat itself, which is supposedly the source of the negative relationship between racial diversity and white racial attitudes. Specifically, we expect that the negative effect of black electoral strength on support for government aid to African Americans and the positive effect of black electoral strength on negative stereotypes of blacks will be stronger among whites with more negative economic evaluations. Given the poor state of the national economy, whites' economic considera- 
tions may have also been more salient during the 2008 election campaign than in recent previous presidential elections. Thus, there are two reasons to expect race to matter more in 2008: (1) increased racial salience due to Obama's candidacy and (2) greater fear of economic competition. Consequently, we expect the interaction between black electoral strength and negative economic evaluations to be stronger in 2008 than in 2000 or $2004 .^{5}$

\section{Data and Methods}

As discussed above, rather than measuring racial context as the percent of a state's population that is black, we depart from the bulk of previous research by focusing on the racial context in the state voting population (i.e., black electoral strength). Our focus on black electoral strength is driven by the RTH, which emphasizes whites' feelings of threat derived from fear that African Americans will gain economic and political power. Consequently, a larger black population among those voting should produce greater threat among whites than a large but less politically active black population. ${ }^{6}$ Black electoral strength is measured using data from the Census Current Population Survey Voting and Registration Supplement File, which includes interviews with about 100,000 adult citizens for each year included in our analysis, as well as questions on voter registration and turnout. While still subject to overreporting, this survey produces reliable estimates of voter turnout (Highton 2005) and has been widely used to estimate registration and voting characteristics of state populations and subpopulations (e.g., Avery and Peffley 2005; Hill and Leighley 1992; Hood et al. 2001; Radicliff and Saiz 1995). Individual-level data on self-reported voter turnout are aggregated to the state level and used to measure the percent of the voting population that is black, which is our measure of black electoral strength. We then match state-level black electoral strength with non-Hispanic white respondents in the 2000, 2004, and 2008 American National Election Studies (ANES).

We use two measures of white racial attitudes as dependent variables. Our first, aid to blacks, taps support for government assistance for African Americans and asks respondents to place themselves on a seven-point scale where low values indicate greater support for the government helping blacks and high values indicate greater support for "blacks helping themselves." Our second measure is derived from two questions tapping negative racial stereotypes. Only two measures of racial stereotypes appear in all three ANES included in our analysis. One asks respondents to place themselves on a seven-point scale where high values indicate greater agreement that most blacks are "lazy" as opposed to "hardworking." The second question asks respondents to place themselves on a similar seven-point scale where high values indicate greater belief that most blacks are "unintelligent" and 
low values indicate greater belief that most blacks are "intelligent." Responses to these two questions are summed to create an additive index of negative stereotypes. The scale has a Cronbach alpha reliability coefficient of .75, which is greater than the accepted cutoff value for acceptability of .7.

To isolate the effect of black electoral strength on support for aid to blacks and negative stereotypes, it is necessary to control for a number of other factors. First, we control for political ideology (high values are associated with more liberal ideology), which may be correlated with both black electoral strength and racial attitudes (Branton and Jones 2006; Glaser 1994). We also control for income, education, age, and gender. Oliver and Mendelberg (2000) find that those with lower levels of education and higher incomes tend to be more racially resentful (see also Baybeck 2006 and Glaser 1994). Others also have found that older individuals and men tend to hold more negative racial stereotypes than younger individuals and women (e.g., Oliver and Mendelberg 2000). Additionally, we control for region (South $=1$, non-South $=0$ ) because individuals from southern states may have more racially conservative preferences (Oliver and Mendelberg 2000; but see Branton and Jones 2006). Southern states are identified as the eleven states comprising the former Confederacy. ${ }^{8}$ Finally, in testing the moderating effect of economic evaluations, we use responses to a question asking respondents to place themselves on a five-point scale where high values indicate greater belief that the national economy has gotten much worse over the last year and low values indicate greater belief that the economy has gotten much better (negative economic evaluations). Use of national economic evaluations is more appropriate than use of personal economic evaluations given that our emphasis is on group threat, which is based on dominant group members' perceptions of their group's size and economic position relative to subordinate groups (Quillian 1995; see also Citrin et al. 1997). ${ }^{9}$

Our analysis includes individual-level (level-1) variables that are nested within state-level (level-2) variables, which means that errors within each level-2 unit are likely correlated. Ignoring the multilevel nature of the data violates the assumption that the errors within the level-2 units are independent, increasing the chances of Type I errors (i.e., rejecting the null hypothesis when no relationship exists; Steenbergen and Jones 2002). Given this, we use multilevel modeling (MLM), which accounts for the nested nature of our data. Coefficients and standard errors for regression using multilevel modeling are interpreted in the same way that OLS regression coefficients are interpreted. ${ }^{10}$ 


\section{Findings}

We begin by examining the effect of black electoral strength on white racial attitudes for all respondents. The first column of Table 1 reports an empty model (i.e., with no independent variables) predicting attitudes toward government aid to blacks. This model simply estimates an intercept and the variance component in the MLM, which tests for whether there is significant variation in the dependent variable accounted for by the level-2 (i.e., state-level) characteristics. This produces a coefficient for the variance component of .27 with a standard error of .07 , demonstrating that there is significant variation in state means for white support for government aid to blacks. Turning to the second column, we find that the effect of black electoral strength on whites' opposition to greater government aid to blacks is in the expected, negative direction, but does not reach statistical significance. We do find that those who are politically conservative, have higher incomes, or have lower levels of education are more likely to think that blacks should help themselves than to think that government should provide greater aid. The variance component in this model is no longer statistically significant, suggesting that the variation in state means identified in the empty model is accounted for by our state-level characteristics.

The third column of Table 1 reports an empty model predicting whites' negative stereotypes. This model produces a variance component coefficient that is statistically significant, which again suggests the presence of meaningful variation in states means for white stereotypes. The fourth column of Table 1 reports the full model predicting negative stereotypes and produces findings consistent with our second hypothesis. Whites living in states with greater black electoral strength are more likely to hold negative racial stereotypes than are whites living in states with less black electoral strength. Individuals who are more politically conservative or have less education also are more likely to hold negative racial stereotypes.

Overall, the findings reported in the first four columns of Table 1 provide mixed support for the RTH. However, we have suggested that the RTH should be stronger under some context than others. We next consider the potential contextual effects of region, the racially-salient 2008 election, and individuals' economic evaluations.

\section{Contextual Effects}

\section{Region}

Our expectation regarding region is that the effect of racial context on white racial attitudes will be stronger among those living in southern states. 


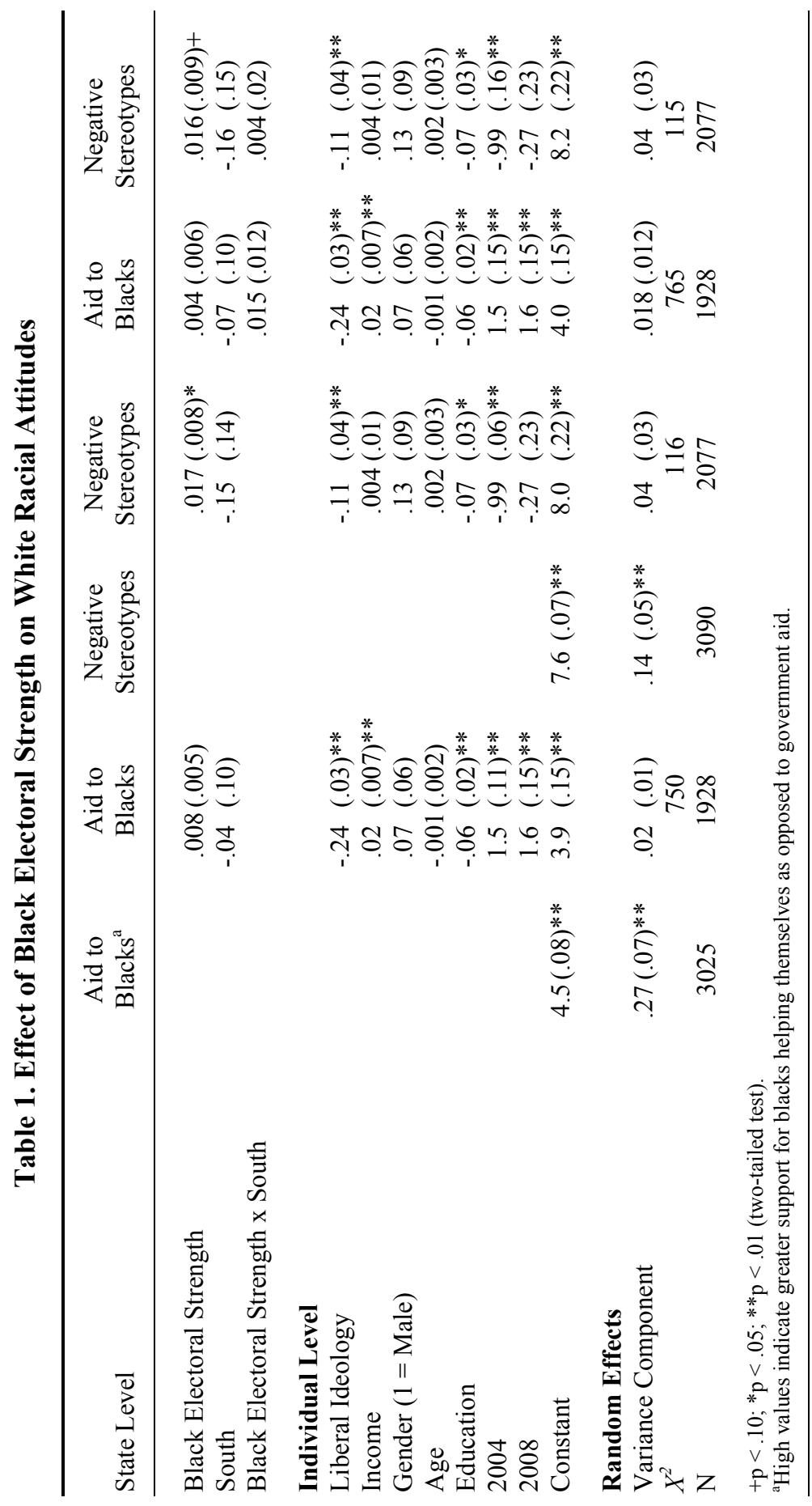


The last two columns of Table 1 report analyses that include the interaction between black electoral strength and the South dummy variable. We find no support for the moderating effect of region: the effect of black electoral strength on the belief that blacks should help themselves and negative stereotypes is no stronger among residents of the South than among those living outside the South. This finding is consistent with recent research that finds support for the RTH throughout the entire nation, not just among whites in the South (Taylor 1998).

\section{The 2008 Election}

We have hypothesized that the news media's focus on increased black voter turnout and the presence of Senator Obama on the presidential ticket raised the salience of race during the 2008 election, making this issue especially important to whites in 2008 as compared to 2000 and 2004. Given this, we expect that racial context will have a stronger influence on white racial attitudes in 2008 than in 2000 or 2004 . To test this hypothesis, we estimate models predicting attitudes toward aid to blacks and negative stereotypes similar to those estimated in the second and fourth columns of Table 1, but now include a dummy variable for respondents from the 2008 ANES and an interaction between this dummy variable and black electoral strength. The results of these analyses are reported in Table 2 . The effect of this interaction is positive and statistically significant for both models, indicating that the effect of black electoral strength on both attitudes toward government aid to blacks and negative racial stereotypes was stronger in 2008 than in 2000 and 2004.

To illustrate the substantive implications of this interactive effect, we estimate expected values for both dependent variables while varying black electoral strength, the 2008 dummy variable, and the interaction between the two. All other variables are held at their mean or modal value as appropriate. The results of these analyses are reported in Figure 1. Figure 1A reports the results for the model predicting attitudes toward government aid to blacks and shows that the positive effect of black electoral strength on the belief that blacks should help themselves exists only for those respondents from the 2008 ANES, not for those interviewed in 2000 or 2004. Moving from the state with the lowest level of black electoral strength ("Min"; Vermont and Idaho) to the state with the highest level ("Max"; Mississippi) is associated with an increase of about one and one-half points on the seven-point aid to blacks scale. ${ }^{11}$ This is a 21 percent increase in racially conservative preferences, an increase we take to be substantive. 
Table 2. Testing for 2008 as Exceptional

\begin{tabular}{|c|c|c|}
\hline State Level & Aid to Blacks & Negative Stereotypes \\
\hline Black Electoral Strength & $.003(.008)$ & $.01 \quad(.01)$ \\
\hline South & $-.11(.13)$ & $-.19(.16)$ \\
\hline \multicolumn{3}{|l|}{ Individual Level } \\
\hline Liberal Ideology & $-.14(.03)^{* *}$ & $-.16(.04)^{* *}$ \\
\hline Income & $.09(.01)^{* *}$ & $-.04(.01)^{* *}$ \\
\hline Gender $(1=$ Male $)$ & $-.10(.06)$ & $.24(.09)^{* *}$ \\
\hline Age & $.005(.02)$ & $.002(.003)$ \\
\hline Education & $-.13(.02)^{* *}$ & $-.02(.03)$ \\
\hline 2008 & $.22(.12)+$ & $.73(.17)^{* *}$ \\
\hline Black Electoral Strength X 2008 & $.03(.01)^{* *}$ & $.03(.01)^{*}$ \\
\hline Constant & $4.2(.16)^{* *}$ & $8.0(.22)^{* *}$ \\
\hline \multicolumn{3}{|l|}{ Random Effects } \\
\hline Variance Component & $.07(.03)^{*}$ & $.06(.04)$ \\
\hline$X^{2}$ & 459 & 74 \\
\hline $\mathrm{N}$ & 1928 & 2077 \\
\hline
\end{tabular}

Turning to Figure 1B, we again see that the positive effect of black electoral strength on the expected values for negative stereotypes only exists for those interviewed during the 2008 election. A shift from the state with the lowest level of black electoral strength to the state with the highest level is associated with about a one and one-half-point increase on the thirteenpoint negative stereotypes scale. This is a more modest $(12 \%)$ increase than that found for aid to blacks, but still substantively meaningful.

Overall, our findings from Table 2 and Figure 1 indicate that the influence of racial context on white racial attitudes is dependent on how salient race is at a particular time. During the 2000 and 2004 elections, periods when race was not as prominent in political discourse, racial context did not influence white racial attitudes. However, the relationship is distinct during the 2008 election, when race was prominent among news media coverage of the presidential election. In 2008, whites in states with greater black electoral strength were less likely to support government aid to blacks and more likely to hold negative racial stereotypes than whites in states with lower levels of black electoral strength. These findings are consistent with our expectations and with the RTH. 
Figure 1. The Effect of Racial Salience of the Times

Figure 1A: Aid to Blacks

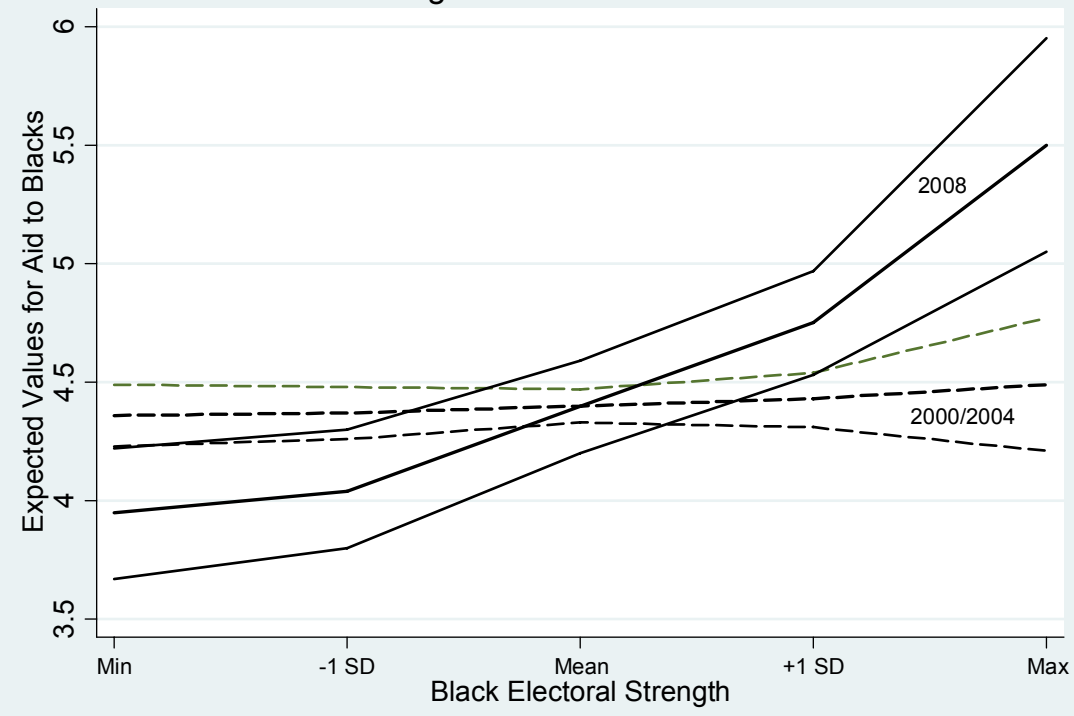

Figure 1B: Racial Stereotypes

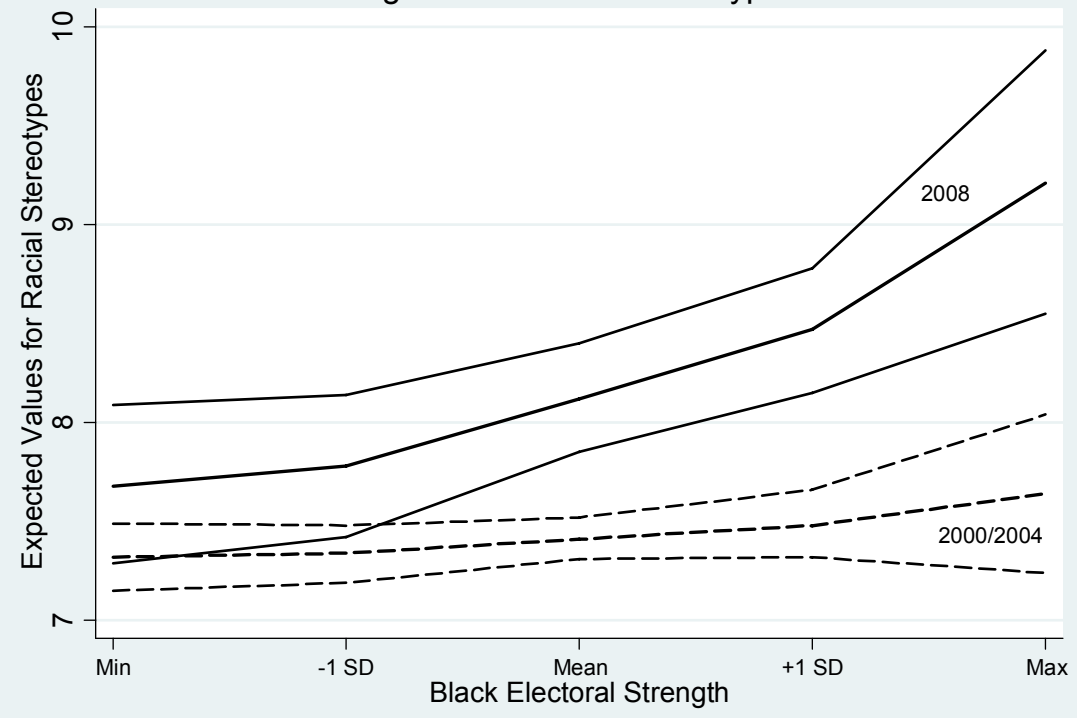




\section{Economic Evaluations}

The final contextual factor we consider is individuals' economic evaluations. We expect that whites with more negative evaluations of the national economy will feel greater economic threat from larger black populations and, consequently, hold more negative racial attitudes. As discussed above, we also expect that this relationship will be strongest in 2008, when the economic threat and threat of black political empowerment were both salient.

In testing this expectation, we estimate models predicting attitudes toward aid to blacks and negative stereotypes that include interactions between black electoral strength, negative economic evaluations, and the 2008 dummy variable. These results are reported in Table 3. The first and third columns of Table 3 report the results when negative economic evaluations are included in the model, but without the interactions. The first column shows that whites with more negative evaluations of the national economy were less supportive of government aid to blacks, whereas no effect of economic evaluations is found in the third column for the model predicting negative stereotypes. The second and fourth columns of Table 3 report the results of the interaction effects. In these models, we include all relevant two-way interactions as well as the three-way interaction between black electoral strength, economic evaluations, and the 2008 dummy variable. Focusing on the latter, we find a positive, moderately significant effect for the model predicting attitudes toward aid to blacks. However, we find no significant effect for the model predicting negative stereotypes.

To illustrate the substantive effect of this interaction on support for aid to blacks, we produce expected values for the aid to blacks scale while varying black electoral strength, negative economic evaluations, the 2008 dummy variable, and the interaction terms while holding other variables at their mean or modal values as appropriate. The results of this analysis are reported in Figure 2. In this figure, "Worse" indicates one standard deviation above the mean on the negative economic evaluations scale, "Same" indicates the mean value, and "Better" indicates one standard deviation below the mean. First, examining the left side of Figure 2, we see that the effect of negative economic evaluations on attitudes toward aid to blacks is not dependent on black electoral strength in 2000 and 2004. Instead, those with more negative evaluations of the economy report less support for aid to blacks than those with more positive evaluations, regardless of level of black electoral strength in their state. Turning to the right side of Figure 2, however, we find support for the importance of economic evaluations in moderating the influence of black electoral strength on attitudes toward government aid to blacks when race is salient. For those interviewed in 2008 who fall one standard deviation above the mean on the negative economic 


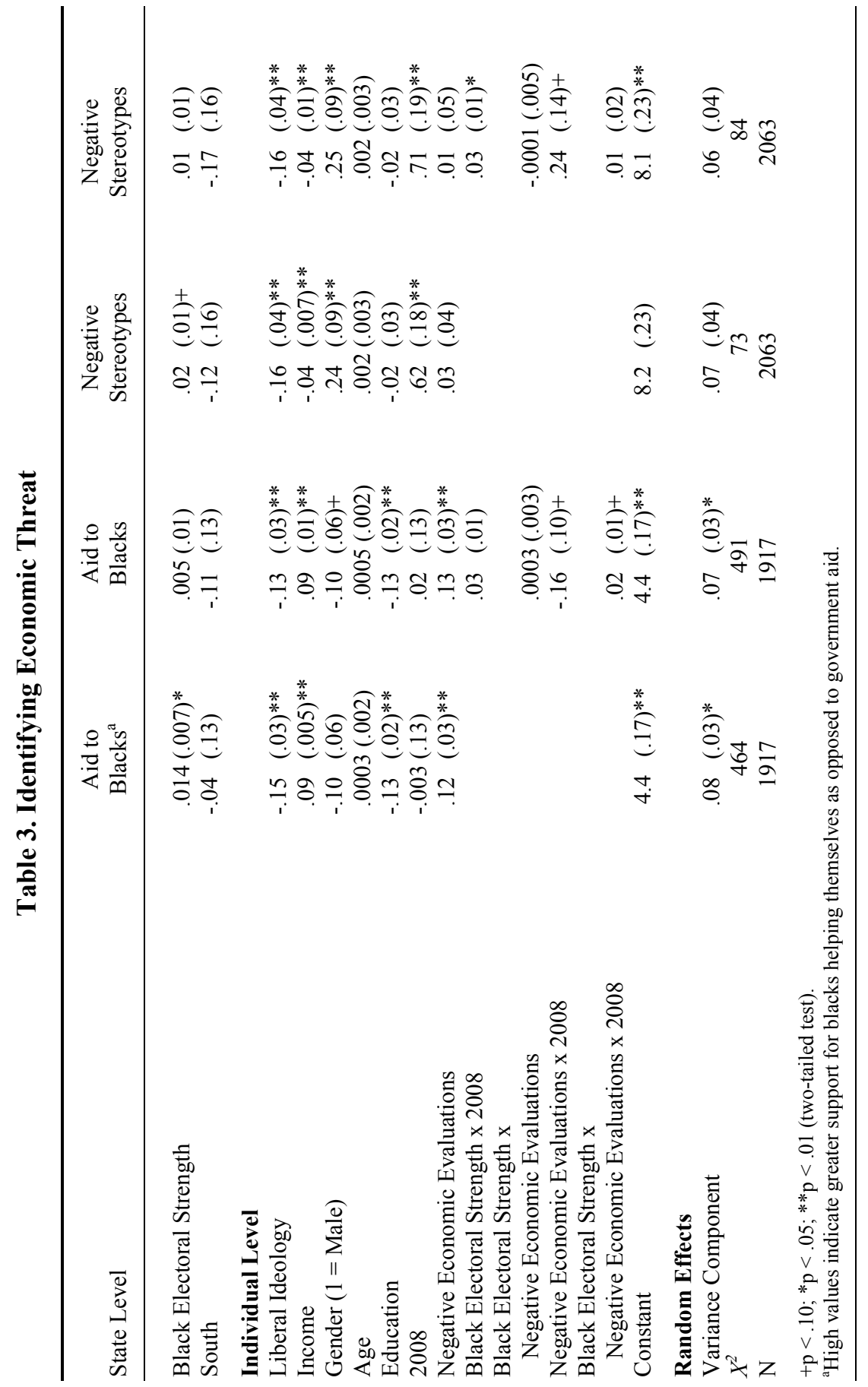


Figure 2. Effect of Economic Threat (2000/2004 vs. 2008)

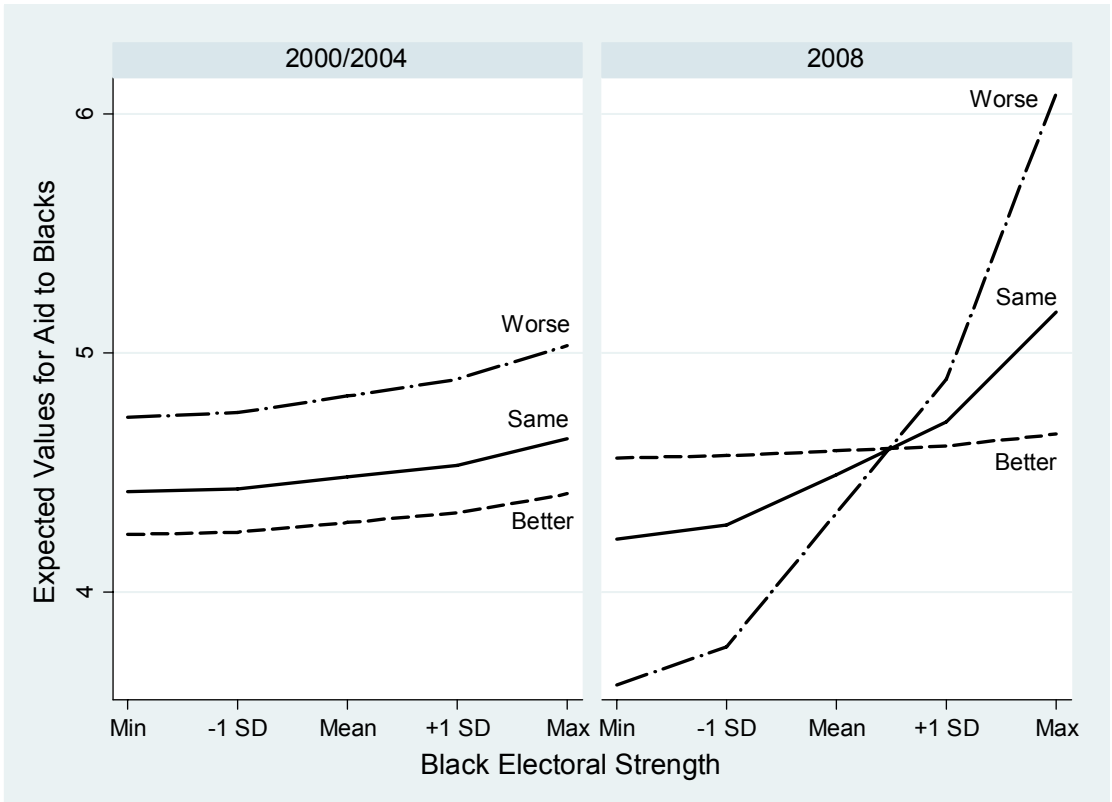

evaluations scale ("Worse"), a shift from the minimum to the maximum value for black electoral strength is associated with about a two and one-half point increase on the seven-point aid to blacks scale. This is roughly a 36 percent increase on this scale, which represents a substantively meaningful effect. For 2008 respondents who are at the mean on the negative economic evaluations scale ("Same"), a much more modest positive effect of black electoral strength is found. Finally, for 2008 respondents falling at one standard deviation below the mean ("Better"), there is no influence of black electoral strength on attitudes toward aid to blacks. In summary, the findings from Table 3 and Figure 2 demonstrate the importance of economic evaluations when considering the influence of racial context on white racial attitudes, though the effect of economic evaluations is dependent on the racial salience of the times.

\section{Discussion}

One primary contribution of the current study is in demonstrating that racial composition of states' electorates influences the racial attitudes of white Americans. We have argued that black electoral strength at the state level should lead to more negative racial attitudes among whites, consistent 
with the RTH. This expectation is based on findings from other studies indicating that geographic contexts characterized by interracial competition without interracial contact should lead whites to feel threatened by minority populations. Our findings are, on the whole, in line with this expectation. While our design does not allow us to examine the influence of racial context on white attitudes at lower levels of aggregation like neighborhoods, we can conclude that the influence of racial diversity at the state level is, in general, consistent with the expectations of the RTH.

Geographic context, however, is not the only context that matters. Thus, our second primary contribution is in identifying two contexts that moderate the relationship between black electoral strength and white racial attitudes. While we find no evidence for region (i.e., South vs. non-South) as a moderating force, we do find that the effect of black electoral strength on white racial attitudes was limited to the 2008 election and to those respondents with more negative evaluations of the national economy. The first finding suggests that the effect of state-level racial context on white racial attitudes is dependent on how racially salient the times are. The second finding indicates that the effect of black electoral strength (i.e., racial context) is limited to whites who have greater reason to feel threatened by potential economic competition from African Americans: those whites with more negative evaluations of the national economy. This finding supports the RTH since economic threat is assumed to be the source of the negative relationship between racial diversity and white racial attitudes. The contextual effect of economic evaluations is also consistent with recent previous research (e.g., Branton and Jones 2005), as well as early theories of racial threat (e.g., Key 1949; Blalock 1967). However, the effect of economic evaluations is observed only during the 2008 election, a period when race was salient in the news and many whites believed that the election of an African American president may lead to worse representation of their interests. On the whole, our findings provide substantial support for the RTH. Black electoral strength leads to more negative racial attitudes among whites, but only when whites have reason to feel threatened; when faced with a mobilized black population and the potential election of an AfricanAmerican president, and when threat of economic competition from blacks is greatest.

Finally, our findings also underscore the importance that racial considerations played during the 2008 presidential election. Some scholars have suggested that white racial attitudes did not play a significant role in vote choice during the 2008 election (e.g., Mas and Moretti 2009). Others estimate that Obama's race cost him five percent of the national vote (LewisBeck et al. 2010) and that racial tension and prejudice among whites played a role in many whites' vote calculus and reduced overall support for Obama 
(Liu 2010; Piston 2010). Regardless of whether racial considerations influenced vote choice, there is no doubt that race was salient during the 2008 election. The national news media gave prominent coverage to the increased turnout among African Americans. This increase in racial salience also is reflected in the large percentages of whites who believed that Obama would represent the interests of blacks at the expense of whites. The current study contributes to scholarly work examining the racial significance of the 2008 election by showing that the salience of race during this election increased the level of racial threat among whites. Specifically, increased racial salience during this election appears to have made relevant the racial composition of one's state when considering negative racial stereotypes and preferences regarding the extent to which government should provide aid to African Americans. This finding reinforces prior research suggesting that AfricanAmerican presidential candidates face greater obstacles to election than do their white counterparts.

\section{NOTES}

${ }^{1}$ The RTH has also been call the "power-threat hypothesis," "racial backlash hypothesis," and "power theory."

${ }^{2}$ The Campaign for Fiscal Equity (CFE; see http://www.cfequity.org/) in New York State provides a real-world example of inter-racial competition for state resources. The CFE filed a constitutional challenge to New York State's school finance system, arguing that the New York City School District was underfunded to the extent that they were denying their students their constitutional right to the opportunity for a sound basic education. While the claim was not overtly race related, the New York City School District serves a disproportionate number of African-American students. Thus, to a great degree, the issues became one of competition over resources between African-American and white students.

${ }^{3}$ Using Lexis-Nexus, we searched for articles appearing in U.S. newspapers during the primary election period, defined as January 1, 200, through August 24, 2008 (the last day before the Democratic Party's Nominating Convention). Our search included any articles on black turnout. Specifically, the articles included needed to contain the term "black," "African American," or "African-American," as well as either "turnout" or "voting." The search yielded nearly 1,000 results. Many of these articles focused on the heightened role that African Americans could have in shaping the outcome of the 2008 election if they mobilized to vote. We limited our search to the primary period to ensure that the coverage was causally prior to the public opinion data contained in the 2008 ANES after the election. If one were to expand the search to include the general election period (i.e., between the Democratic Nominating Convention and Election Day), the number of articles would be even higher.

${ }^{4}$ In testing the effect of racial salience of an election, we would prefer to include more than one election with a viable African-American candidate. However, 2008 represents the only such election (with Barack Obama winning the Democratic nomination and presidency). While Jesse Jackson ran for Democratic nomination in 1984 and 1988, he was never a competitive candidate. Consequently, we would not expect his candidacy to 
provoke the type of racial threat among whites necessary to influence their racial attitudes.

${ }^{5}$ While beyond the scope of the current study, there are other factors that may moderate the effect of racial composition on the quality of black representation. For example, racial threat may be quelled by greater black descriptive representation at the state level. Research at the local level finds that many whites feel less racial threat when they have black elected officials (Hajnal 2001). Whether this applies to the state level is not obvious, however.

${ }^{6}$ Rudolph and Popp (2010) use a similar rationale for using black empowerment through business ownership as a source of white racial threat rather than simply using racial composition in the population.

${ }^{7}$ Overreporting of voter turnout would be problematic if rates of overreporting are higher for African Americans than whites, which early research found to be the case (Abramson and Claggett 1986; Hill and Hurley 1984). However, this is not problematic for the current study. Recent research finds that while blacks are more likely to overreport, whites living in regions with larger black populations, as well as whites living in the Deep South, also are more likely to overreport voting (Bernstein et al. 2001). Thus, in states with larger black populations we would expect exaggerated reporting of turnout among both African Americans and whites. Given this, we have no reason to expect the estimated effect of black electoral strength on white racial attitudes will be biased.

${ }^{8}$ Our findings regarding the influence of the South are substantially identical if Border States are included among "southern" states.

${ }^{9} \mathrm{We}$ have run models to test for a possible interactive effect between black electoral strength and personal economic evaluations or state-level unemployment rates. These analyses find no significant effects, and are not reported, but are available from the authors upon request.

${ }^{10}$ It is possible that individuals self-select into geographic contexts that are consistent with their racial attitudes. That is, it is possible that whites with negative racial attitudes choose to live in areas with less racial diversity. This possibility does not pose a threat to our analysis since such behavior would lead to a negative relationship between racial diversity and white racial attitudes, whereas we expect a positive relationship. This possibility would bias our model against finding such a relationship if one exists (i.e., a Type II error), and thus strengthen our confidence in our results if a positive relationship is present.

${ }^{11}$ Minnesota is roughly one standard deviation below the mean of black electoral strength (three percent in 2004). Ohio and Florida have values close to the mean (11\%). Virginia and North Carolina are approximately one standard deviation above the mean $(19 \%)$.

\section{REFERENCES}

Abramson, Paul, and William Claggett. 1986. "Race-Related Differences in SelfReported and Validated Turnout in 1984." Journal of Politics 48:412-422.

Allport, Gordon W. 1954. The Nature of Prejudice. Reading, MA: Addison-Wesley.

Amir, Yehuda. 1976. The Role of Intergroup Contact in Change of Prejudice and Ethnic Relations. Pp. 245-308 in Towards the Elimination of Racism, ed. Phyllis A. Katz. New York: Pergamon. 
Ansolabehere, Stephen, Nathaniel Persily, and Charles Stewart III. 2010. Race, Region, and Vote Choice in the 2008 Election: Implications for the Future of the Voting Rights Act. Harvard Law Review 123:1385-1436.

Avery, James M., and Mark Peffley. 2005. Voter Registration Requirements, Voter Turnout, and Welfare Eligibility Policy: Class bias Matters. State Politics and Policy Quarterly 5:47-67.

Balz, Dan, Anne E. Kornblut, and Shailagh Murray. 2008. Obama is Big Winner in S.C.; Clinton 2nd After Bitter Campaign. Washington Post, January 27, p. A01.

Baybeck, Brady. 2006. Sorting Out the Competing Effects of Racial Context. Journal of Politics 68:386-96.

Bernstein, Robert, Anita Chadha, and Robert Montjoy. 2001. Overreporting Voting: Why it Happens and Why it Matters. Public Opinion Quarterly 65:22-44.

Black, Earl, and Merle Black. 1987. Politics and Society in the South. Cambridge, MA: Harvard University Press.

Black, Merle. 1978. Racial Composition of Congressional Districts and Support for Federal Voting Rights in the American South Social Science Quarterly 59:435-450.

Blalock, Hubert M. 1967. Toward a Theory of Minority-Group Relations. New York: John Wiley \& Sons.

Bledsoe, Timothy, Susan Welch, Lee Sigelman, and Michael Combs. 1995. Residential Context and Racial Solidarity among African Americans. American Journal of Political Science 39:434-58.

Branton, Regina P., and Bradford S. Jones. 2005. Reexamining Racial Attitudes: The Conditional Relationship between Diversity and Socioeconomic Environment. American Journal of Political Science 49:359-372.

Campbell, D.T. 1965. Ethnocentric and Other Altruistic Motives. In D. Levine, ed., Nebraska Symposium on Motivation, Current Theory and Research on Motivation 13:283-311. Lincoln: University of Nebraska Press.

Carsey, Thomas M. 1995. The Contextual Effects of Race on White Voter Behavior: The 1989 New York City Mayoral Election. Journal of Politics 57:221-228.

Citrin, Jack, Donald P. Green, Christopher Muste, and Cara Wong. 1997. Public Opinion Toward Immigration Reform: The Role of Economic Motivations. Journal of Politics 59:858-81.

Giles, Micheal W., and Melanie A. Buckner. 1993. David Duke and Black Threat: An Old Hypothesis Revisited. Journal of Politics 55:702-713.

Glaser, James M. 1994. Back to the Black Belt: Racial Environment and White Racial Attitudes in the South. Journal of Politics 56:21-41.

Glaser, James M. 2001. The Preference Puzzle: Educational Differences in RacialPolitical Attitudes. Political Behavior 23:313-34.

Hajnal, Zoltan L. 2001. White Residents, Black Incumbents, and a Declining Racial Divide. American Political Science Review 95:603-17.

Highton, Benjamin. 2005. Self-reported Versus Proxy-reported Voter Turnout in the Current Population Survey. Public Opinion Quarterly 69:113-123.

Hill, Kim Quaile, and Patricia Hurley. 1984. Nonvoters in Voters' Clothing: The Impact of Voting Behavior Misreporting on Voting Behavior Research. Social Science Quarterly 65:153-166.

Hill, Kim Quaile, and Jan E. Leighley. 1992. The Policy Consequences of Class Bias in State Electorates. American Journal of Political Science 36:351-365.

Hood, M.V., Quentin Kidd, and Irwin L. Morris. 2001. The Key Issue: Constituency Effects and Southern Senators' Roll-Call Voting on Civil Rights. Legislative Studies Quarterly 26:599-621. 
Huckfeldt, Robert, and Carol Weitzel Kohfeld. 1989. Race and the Decline of Class in American Politics. Urbana: University of Illinois Press.

Hulse, Carl. 2008. New Registrations Give Georgia Blacks More Power at the Polls. New York Times, October 30, p. A18.

Key, Jr., V.O. 1949. Southern Politics in State and Nation. Knoxville: University of Tennessee Press.

Kuklinski, James H., Michael D. Cobb, and Martin Gilens. 1997. Racial Attitudes and the 'New South.' Journal of Politics 59:323-349.

Leary, Alex. 2008. Black Voters Could Be Key. St. Petersburg Times, October 4, p. 1 B.

Lewis-Beck, Michael S., Charles Tien, and Richard Nadeau. 2010. Obama's Missed Landslide: A Racial Cost? PS: Political Science \& Politics 43:69-76.

Liu, Baodong. 2010. The Election of Barack Obama: How He Won. Palgrave Macmillan.

Liu, Baodong. 2001. Racial Contexts and White Interests: Beyond Black Threat and Racial Tolerance. Political Behavior 23:157-180.

Mas, Alexandre, and Enrico Moretti. 2009. Racial Bias in the 2008 Presidential Election. American Economic Review 99(2):323-329.

Massey, Douglas. 2000. The Residential Segregation of Blacks, Hispanics, and Asian 1970-1990. Pp. 44-73 in Immigration and Race, ed. Gerald Jays. New Haven, CT: Yale University Press.

Oliver, Eric J., and Tali Mendelberg. 2000. Reconsidering the Environmental Determinants of White Racial Attitudes. American Journal of Political Science 44:574-589.

Oliver, Eric J., and Janelle Wong. 2003. Intergroup Prejudice in Multiethnic Settings. American Journal of Political Science 47:567-582.

Pettigrew, Thomas F. 1971. Racially Separate or Together? New York: McGraw-Hill.

Piston, Spencer. 2010. How Explicit Racial Prejudice Hurt Obama in the 2008 Election. Political Behavior 32:431-452.

Quillian, Lincoln. 1995. Prejudice as a Response to Perceived Group Threat: Population Composition and Anti-Immigrant and Racial Prejudice in Europe. American Sociological Review 60:586-611.

Radcliff, Benjamin, and Martin Saiz. 1995. Race, Turnout, and Public Policy in the American States. Political Research Quarterly 48:775-794.

Rocha, Rene R., and Rodolgo Espino. 2009. Racial Threat, Residential Segregation, and the Policy Attitudes of Anglos. Political Research Quarterly 62:415-426.

Rudolph, Thomas J., and Elizabeth Popp. 2010. Race, Environment, and Interracial Trust. Journal of Politics 72:74-89.

Sigelman, Lee, and Susan Welch. 1993. The Contact Hypothesis Revisited: Black-White Interaction and Positive Social Attitudes Social Forces 71:781-795.

Soss, Joe, Sanford F. Schram, Thomas P. Vartanian, and Erin O’Brien. 2001. Setting the Terms of Relief: Explaining State Policy Choices in the Devolution Revolution. American Journal of Political Science 45:378-395.

Steenbergen, Marco R., and Bradford S. Jones. 2002. Modeling Multilevel Data Structures. American Journal of Political Science 46:218-237.

Taylor, Maryless C. 1998. How White Attitudes Vary with the Racial Composition of Local Populations: Numbers Count. American Sociological Review 63:512-535.

Welch, Susan, Lee Sigelman, Timothy Bledsoe, and Michael Combs. 2001. Race and Place: Race Relations in an American City. New York: Cambridge University Press.

Wright Jr., Gerald C. 1977. Contextual Models of Electoral Behavior: The Southern Wallace Vote. American Political Science Review 71:497-450. 